\title{
POTENSI PENGEMBANGAN PRODUK PEMBIAYAAN MUDHARABAH DI BANK SYARIAH PADA SEKTOR RIIL UMKM
}

\author{
Trimulato \\ Universitas Islam Indonesia \\ e-mail: trimsiuii@yahoo.co.id
}

\begin{abstract}
Shari'ah banking currently has a strong legal standing with the presence of the Undang- Undang 21, 2008 on banking Shari'ah. It is very influential on the existence of the banking Shari'ah are increasingly in demand by many. Islamic bank is better known by the profit-sharing system has a range of products that use Mudaraba and Musharaka contract, considered more equitable for all parties. But from the available data suggests that the financing is not dominant. Murabaha Islamic banks is greater than the mudaraba. Islamic economics can not be separated from the real sector, especially SMEs, its existence requires the support of other parties, including Islamic banks. Financing products with mudharabah it is appropriate to sustain the business capital of SMEs. Based on data from the central statistical agency that the growth of SMEs in 2010 amount to 55,206,444 units in 2012 to 56,534,592 units experiencing good growth, so it takes a good response for Islamic banks. This paper uses a descriptive qualitative limitations in this paper is focused on products of financing in Islamic bank and real sector SMEs. This paper uses literature study from various sources. The results of this paper that the potential for product development in Islamic bank financing is still very large. It is seen that the number of SMEs continues to grow, then the portion of financing products are still small. This shows that the products of financing in Islamic banks are very suited to the conditions and character of SMEs. Mudharabah product development potential is still very large and very spacious.
\end{abstract}

Keywords: Bank of Shariah, Mudharabah and real sector SMEs

\section{PENDAHULUAN}

Seiring dengan perbaikan dan reformasi perbankan nasional pasca krisis ekonomi, perbankan syari'ah yang merupakan bagian dari perbankan nasional mulai memasuki babak baru implementasi sistem perbankan nasional dengan segala hambatan dan perkembangan yang secara berkala terus diperbaiki sesuai dengan syariat Islam. Perbankan syari'ah era reformasi dimulai dengan disetujuinya Undang-undang No.10 tahun 1998 tentang perbankan syari'ah (Antonio, 2001:26). Kemudian disempurnakan dengan adanya undang-undang Perbankan Syari'ah nomor 21 tahun 2008.

Ide dasar sistem perbankan Islam sebenarnya dapat dikemukakan dengan sederhana.Operasi institusi keuangan Islam terutama berdasarkan pada prinsip PLS (porfit-and-loss-sharing bagi untung dan rugi). Prinsip bagi hasil ini dalam keuangan Islam sangat dianjurkan dan merupakan solusi yang pantas dan relefan untuk mengatasi masalah alokasi dana yang terbatas, baik yang berupa dana pinjaman atau tabungan dengan maksud supaya pengelolaan dan pembiayaan bisnis secara efektif dapat tercapai. Bank Islam tidak membebankan 
bunga, melainkan mengajak partisipasi dalam bidang usaha yang didanai.Para deposan juga sama-sama mendapat bagian dari keuntungan bank sesuai dengan rasio yang telah ditetapkan sebelumnya. Dengan demikian ada kemitraan antara bank Islam dan para deposan di satu pihak, dan antara bank para nasabah investasi sebagai pengelola sumber daya para deposan dalam berbagai usaha produktif dipihak lain (Algaoud, 2001:9-10).

Alasan didirikannya bank syari'ah diantaranya karena keadilan yang terdapat pada bank syari'ah. Di kalangan investor Barat terjadi pergeseran paradigma dalam berinvestasi yaitu mereka tidak lagi berinvestasi karena alasan tertarik dengan bunga yang kelihatannya saja menjanjikan keuntungan berlipat ganda seketika.Namun kini mereka lebih kritis penghasilan yang mungkin diperoleh melalui metode institusi pemutaran uang, sehingga sistem bagi hasil yang diterapkan oleh bank syari'ah lebih logis dan fair bagi mereka. Dengan adanya bank syari'ah maka semua umat terutama umat Islam terhindar dari riba dalam kegiatan muamalahnya memperoleh kesejahteraan lahir batin dan sesuai dengan perintah agamanya.

Karakteristik sistem perbankan syari'ah yang beroperasi berdasarkan prinsip bagi hasil memberikan alternatif sistem perbankan yang saling menguntungkan bagi masyarakat dan bank, serta menonjolkan aspek keadilan dalam bertransaksi, investasi yang beretika, mengedepankan nilai-nilai kebersamaan dan persaudaraan dalam berproduksi, dan menghindari kegiatan spekulatif dalam bertransaksi keuangan. Dengan menyediakan beragam produk serta layanan jasa perbankan yang beragam dengan skema keuangan yang lebih bervariatif, perbankan syari'ah menjadi alternatif sistem perbankan yang kredibel dan dapat dinimati oleh seluruh golongan masyarakat Indonesia tanpa terkecuali (www.bi.go.id).

Bank syari'ah lebih dikenal dengan sistem bagi hasil yang mempunyai berbagai produk yang menggunakan akad Mudharabah dan Musyarakah, dianggap lebih adil bagi semua pihak.Namun saat ini sepertinya sudah mulai terjadi pergeseran di bank syari'ah, Bank syari'ah lebih senang dan lebih mengunggulkan produk pembiayaan dengan akad Murabahah, yang memberikan hasil yang pasti.Bisa dilihat perbandingan pembiayaan di bank syari'ah dengan menggunakan akad Mudharabah dan akad Murabahah. Berdasarkan statistik Bank Indonesia, jumlah pembiayaan yang telah disalurkan oleh industri perbankan syari'ah hingga Oktober 2013 tercatat senilai Rp179,28 triliun, tumbuh $32,23 \%$ dari posisi Rp135,58 triliun pada periode yang sama tahun lalu (www.insco.co.id).

Tabel 1

Produk Pembiayaan di Bank Syari'ah (Dalam Milyar Rupiah)

\begin{tabular}{cccc}
\hline NO & AKAD & Maret 2014 & April 2014 \\
\hline 1 & Mudharabah & 13.498 & 13.802 \\
2 & Murabahah & 111.727 & 112.288 \\
\hline \multicolumn{2}{c}{ Sumber : Otoritas Jasa Keuangan, $2014: 30$}
\end{tabular}

Jika melihat data diatas terlihat sangat jauh perbandingan pembiayaan yang dilakukan oleh bank syari'ah antara yang menggunakan akad mudharabah dengan produk pembiayaan yang menggunakan akad murabahah. Keputusan bank syari'ah lebih memilih produk murabahah karena akad ini lebih memberi kepastian terhadap tingkat pengembalian. Bank syari'ah juga belum begitu berani 
untuk menanggung resiko, jika menggunakan akad mudharabah.

Bank Syariah merupakan bagian yang tidak bisa dipisahkan dari konsep ekonomi islam. Jika ingin digambarkan ekonomi islam itu ibarat sebuah pohon, dan bank syariah menjadi bagian selembar daun yang berada dalam tubuh pohon itu. Cakupan ekonomi islam begitu luas, bank syariah menjadi bagian kecil yang dibahas di dalamnya. Ekonomi islam sangat erat kaitannya dengan sektor riil, bahkan dalam ekonomi islam sektor riil jauh lebih utama ketimbang sektor keuangan. Dalam ekonomi islam sektor keuangan hanya sebagai bagian pendukung dalam suatu perekonomian, dan sektor riil adalah penopang utama sistem perekonomian. Maka dari itu bank syariah adalah bagian dari sistem ekonomi islam dan merupakan sektor keuangan yang harus bisa mendukung laju perkembangan sektor riil, menjaga stabilitas ekonomi dan bisa menambah pendapatan suatu negara, dan lebih jauh bisa menciptkan banyak lapangan kerja.

Konon katanya jika dihitung pendapatan rata-rata masyarakat Indonesia sama besarnya pendapatan rata-rata Negara maju. Hanya saja di Indonesia sebagian pihak kekayaannyanya menjulang naik setinggi langit sedangkan ada pihak yang amat memprihatinkan tidak mampu memenuhi kebutuhan primer. Hal semacam ini yang tidak berlaku dalam ekonomi islam, pemberdayaan masyarakat guna pengembangan sektor rill harus ditingkatkan dan peran masyarakat dalam tataran ekonomi domestik harus mendapatkan perhatian lebih dari semua pihak. Ekonomi domestik adalah ekonomi kita yang sebenarnya, tidak akan ada campur tangan dari Negara lain sehingga jika terjadi masalah ekonomi dengan Negara lain maka tidak memberikan dampak apapun bagi Negara ini. Terbukti jika terjadi krisis ekonomi dunia maka perekonomian domestik menjadi perhatian dan solusi mengatasinya, sebab tidak terkena dampaknya. Jadi sebaiknya ekonomi di sektor rill khususnya tataran domestik harus menjadi perhatian bersama terutama bagi pemerintah. Peluang tetap terbuka dari sejumlah keunggulan yang kini ada dalam perekonomian Indonesia, seperti pasar dalam negeri yang besar, peluang investasi yang masih terbuka luas, dan sejumlah produk unggulan di pasar ekspor. Adanya intervensi pemerintah dalam ekonomi islam terhadap perekonomian sangat dibutuhkan, sebab Negara menjadi wadah terciptanya kesejahteraan ummat manusia. Dalam kepemilikan individu tidaklah bersifat mutlak, namun kepemilikan itu dibatasi oleh beberapa hal. Dalam beberapa kondisi, negara mempunyai hak intervensi terhadap kepemilikan, hak untuk membatasi atau mengatur kepemilikan itu dalam kehidupan masyarakat (Sami', 2006:46). Perekonomian domestik dalam pengembangannya juga dibutuhkan pihak yang memberikan kemudahan dalam permodalan sehingga pemberdayaan masyarakat dapat tercipta.

Dari uraian ini menjadi sangat penting bagi bank syariah untuk bisa berkontribusi dalam mengembangkan ekonomi domestik khusunya bagi Usaha Kecil dan Menengah (UMKM). Perlu buat desain produk yang bisa memberi jalan bagi bank syariah untuk bisa bersatu mengembangkan usaha kecil dan menenghah (UMKM). Saat ini bermuculan upaya bank syariah untuk bisa memmberikan pembiayaan pada sektor UMKM. Krisis yang melanda bangsa Indonesia telah meluluh lantakkan segala sendi-sendi kehidupan termasuk juga sektor perbankan yang juga di pandang sebagai salah satu pemicunya, yaitu dengan disalurkannya kredit-kredit yang salah sasaran. Krisis membuktikan bahwa usaha kecil menengah yang jumlah sangat banyak mampu bertahan menghadapi krisis tersebut secara mandiri. Disaat perekonomian kini mulai 
menunjukkkan geliat untuk bangkit kembali, usaha kecil menengah nampaknya seolah kembali terlupakan, terutama lagi dengan banyak masuk dan beroperasinya usaha asing - termasuk perbankan asing pasca periode penjualan aset-aset perbankan nasional. Perbankan syariah yang telah dirintis sejak tahun 1992 nampaknya kini dapat menjadi harapan baru bagi pengembangan usaha kecil menengah, khususnya dalam pengadaan modal kerja. Dari peristiwa krisis yang telah melanda bangsa Indonesia tersebut telah menciptakan kemiskinan bagi sebagian kalangan masyarakat kita yang sifatnya terstruktur, melalui pemberdayaan perbankan syariah ini harapan kita akan bisa menangani kemiskinan dengan menghilangkannya melalui proses trickle down effect. Akibatnya kemungkinan terjadinya ketimpangan distribusi dan akses sumber daya ekonomi. Karena pendekatan ini butuh biaya besar dan harus ditanggung oleh negara (mengandalkan pinjaman luar negeri). Untuk mengatasi permasalahan yang telah terjadi selama ini terhadap Negara kita yang selalu mengandalkan ketergantungan kepada bantuan dari luar nergeri salah satu langkah yang dianggab efektif adalah menggunakan keuangan mikro sebagai metode utama. Kontribusi pendekatan ini terdiri dari diversifikasi pelaku utama pembangunan adalah masyarakat, pembiayaan pembangunan yang menggunakan sumber keuangan masyarakat sendiri serta menerapkan pendekatan pembangunan yang memiliki potensi untuk berlanjut (sustainable). Beranjak dari permasalahan itu, kita sebagai Subyek yang akan menentukan masa depan bangsa kita tidak akan mingkin bergantung secara terus menerus terhadap upaya- upaya tersebut. Kita harus berupaya mencari terobosanterobosan lain yang justru memberikan harapan yang lebih menjanjikan terhadap masa depan perekonomian kita. Saat sekarang ini seiring dengan berkembangnya pola pikir masyarakat Indonesia pada umumnya, telah bisa melahirkan terobosan- terobosan baru dalam rangka pengembangan ekonomi bangsa, dari banyak terobosan- terobosan tersebut salah satunya dapat kita amati dari segi perkembangan sector Asaha Kecil dan Menengah (www.kompasiana.com).

PT Bank Syariah Mandiri (BSM) optimis kontribusi pembiayaan segmen usaha mikro, kecil dan menengah (UMKM) dapat terus dipertahankan. Untuk tahun ini, perseroan mematok porsinya mencapai $75 \%$ dari total pembiayaan yang ditargetkan tumbuh $25 \%$ menjadi Rp55,96 triliun. Demikian porsi UMKM diharapkan mencapai Rp42 triliun. "BSM sengaja mengejar yang ritel baik dana dan pembiayaan. Jadi kami agak puasa untuk yang korporasi, institusi yang besar-besar dananya," ujar Direktur Utama BSM Yuslam Fauzi, saat ditemui wartawan di Kantor Pusat BSM, Jakarta, belum lama ini. Perseroan mencatat per akhir 2012, kucuran pembiayaan UMKM mencapai Rp32,79 triliun, atau sebesar $73,3 \%$ dari total pembiayaan sebesar Rp44,76 triliun. Pada akhir 2011, posisi pembiayaan UMKM sebesar Rp26,78 triliun, sebesar $72,9 \%$ dari total pembiayaan Rp36,73 triliun. Pertumbuhan pembiayaan UMKM sendiri sebesar $22,45 \%$ dalam setahunan, yang juga dikontribusi pembiayaan di segmen mikro. "Kami PD (percaya diri) masuk ke mikro. Pertama IT sekarang, sehingga kami akan lebih gesit dan efisien. Kedua, Bank Mandiri juga sudah mulai kembangkan mikronya. Sebagai bank syariah, lanjutnya, BSM berusaha menjalankan nilai-nilai syariah yang salah satunya adalah dengan memberikan manfaat sebesarbesarnya bagi lingkungan dan masyarakat. Kenyataan mayoritas usaha di Tanah Air adalah usaha mikro dan kecil, lanjutnya, maka perseroan menetapkan untuk masuk ke segmen ini(www.syariahmandiri.co.id). 
Beberapa tahun ini sejumlah bank berkonsep ekonomi Islam ini memiliki program memberi pembiayaan terhadap UMKM. Tujuannya agar para pelaku UMKM bisa semakin berkembang dan terus berkontribusi bagi percepatan pembangunan nasional. Salah satu produk perbankan syariah yang menyentuh para pelaku UMKM adalah kredit usaha rakyat (KUR). Hampir semua bank konvensional yang memiliki produk syariah bergerak di produk ini, seperti beberapa di antaranya Kredit Mikro BRI Syariah, KUR Syariah Mandiri, KUR BNI Syariah, KUR Bank Jatim Syariah, dan KUR Bank Nagari Syariah. Bahkan, tahun ini KUR Syariah Mandiri menyalurkan dana sebesar Rp1,7 triliun. Angka ini naik dua kali lipat dibandingkan 2012, yang hanya Rp750 miliar.

Bank-bank syariah lain juga melakukan hal ini dalam rangka membantu pelaku UMKM yang selama ini merasa kesulitan untuk mengakses permodalan ke bank-bank besar. Pasalnya, selama ini masih ada saja perbankan besar yang enggan mengeluarkan kredit untuk usaha kecil dan baru karena dinilai belum jelas prospeknya. Selain bertujuan membantu memberi akses permodalan kepada UMKM, di tubuh perbankan syariah, optimalisasi terhadap pembiayaan di sektor mikro menjadi salah satu potensi bisnis yang baik untuk masa depan.

Konsultan ekonomi syariah sekaligus Managing Director at Rasyidin Consulting Wiku Suryomurti mengatakan, dalam beberapa tahun ini perbankan syariah terus gencar menyalurkan dana bagi para pelaku UMKM. Pada satu sisi pencapai target pangsa pasar 5\% memang belum tercapai (hanya 4,8\%), tapi di sektor pembiayaan UMKM kinerja bank-bank syariah mulai maksimal. Di Indonesia, ada sekitar 52 juta UMKM yang eksis hingga hari ini. Sayangnya, keberadaan mereka belum banyak terakomodasi permodalan oleh bankbank besar. Sebagian perbankan besar masih khawatir terhadap keberlanjutan UMKM tersebut. Sementara itu, kata Wiku, dalam hal ini perbankan syariah lebih mengakomodasi mereka. Pasalnya, sistem perbankan syariah lebih minimalis tingkat pengaruhnya terhadap gejolak ekonomi (www.bankmuamalat.co.id).

Dari uraian diatas menujukkan bahwa bank syariah sudah mulai melirik untuk mengambil bagian dalam memberikan pembiayaan pada sekrot riil khususnya UMKM, yang menjadi maslah dibutuhkan desain produk yang tepat dalam melakukan pembiayaan terhadap UMKM, kita ketahui bahwa pengusaha UMKM masih sulit dalam akses pembiaayan perbankan syariah. Bank syariah punya produk pembiayaan dengan akad mudharabah yang menggunakan sistem bagi hasil. Produk ini menjadi identitas perbankan syariah sebagai bank bagi hasil bukan bank jual beli, maka seharusnya bank syariah menggunakan akad mudharabah dalam memberikan pembiayaan UMKM. Pada tulisan ini akan diuraikan potensi pengembangan produk mudharabah bank syariah pada sektor riil khususnya UMKM.

Berdasarkan latar belakang yang telah dipaparkan dan beberapa ulasan yang ada terkait dengan produk pembiayaan mudharabah yang ada di bank syari'ah sebagai instrumen yang digunakan dalam produk penyaluran dana, maka dibutuhkan inovasi dalam membuat desain produk mudharabah dalam melakukan pembiayaan bagi UMKM. Hal ini dengan tujuan agar memacu minat pemilik UMKM untuk memilih produk pembiayaan mudharabah di lembaga keuangan syari'ah, khususnya di perbankan syari'ah. Terdapat dua permasalahan utama yang masih dihadapi oleh industri perbankan syariah pada produk penyaluran dana, antara lain; 1) Produk penyaluran dana bank syariah, hampir menyerupai produk bank konvensional, hanya berbeda pada ketentuan sesuai syari'ah belum terlihat produk yang berbeda secara mencolok; 2) Produk 
pembiayaan mudharabah di bank syari'ah belum maksimal dalam menyalurkan dana kepada masyarakat, kecenderungan bank syariah masih menggunakan pembiayaan murabahah, padahal akad yang identik dengan bank syariah adalah akad mudharabah Sehingga dibutuhkan upaya agar potensi akad mudharabah bisa lebih digunakan untuk pembiayaan sektor rill khususnya untuk UMKM.

Rumusan masalah dalam penelitian ini adalah: 1) Bagaimana produk pembiayaan mudharabah di bank syariah serta 2) Bagaimana potensi perkembangan produk pembiayaan mudharabah di bank syariah bagi sektor riil UMKM. Tujuan dari tulisan ini adalah untuk: 1) Mengetahui tentang produk penyaluran dana mudharabah yang ada di bank syari'ah, 2) Mengetahui potensi pengembangan produk pembiayaan mudharabah di bank syariah bagi sektor riil khususnya UMKM.

Tulisan ini diharapkan dapat memberikan kontribusi bagi beberapa pihak, memberikan manfaat kepada; 1) Dunia Praktis Perbankan Syari'ahdengan segera ditindaklanjuti sehingga mampu menjadikan berupa rekomendasi dan bahan masukan bagi manajemen bank syari'ah dalam membuat kebijakan yang berkaitan dengan pengembangan produk pembiayaan mudharabah di bank syari'ah. Serta tulisan ini diharapkan memberi manfaat berupa perangsang bagi semua pihak di bank syari'ah mau berinovasi dalam mengedepankan produk pembiayaan mudharabah bagi sektor riil khususnya UMKM. 2) Dunia Akademisi, diharapkan bisa menjadi koleksi khasanah ilmiah dalam rangka peningkatan dan pengembangan produk bank syari'ah yang juga dikaji di lembaga pendidikan. Serta menerangkan peran bank syariah bagi UMKM. 3) Umum, Tulisan ini diharapkan menjadi bahan pertimbangan bagi masyarakat dalam melibatkan diri dalam memilih produk perbankan syari'ah.

Sebelum melakukan penelitian, peneliti berusaha menelaah literatur karya ilmiah sebelumnya yang berkaitan dengan judul yang diteliti.Hasil penelitianpenelitian yang pernah dilakukan sebelumnya perlu dikemukakan sebagai bahan perbandingan dengan penelitian yang dilakukan penulis. Adapun karya-karya ilmiah yang relevan dengan topik yang peneliti angkat antara lain:

Muslimin Kara dalam tulisannya menyebutkan perkembangan pembiayaan perbankan syariah dalam upaya pengembangan UMKM di Kota Makassar selama tahun 2010-2011 mengalami peningkatan yang berfluktuasi. Hal tersebut mencerminkan bahwa peran serta pembiayaan perbankan syariah dalam peningkatan usaha mikro kecil dan menengah (UMKM) di Kota Makassar belum optimal. Secara rata-rata perkembangan pembiayaan perbankan syariah selama periode Januari - Desember 2010 sebesar 14,23\%, sedangkan periode Januari - September tahun 2011 sebesar 18,43\% (Kara, 2013:300).

Hilman Hakiem dan Desi Silfiaratih Waluyo dalam Jurnal Ekonomi Islam Al-Infaq menyimpulkan dari hasil penelitiannya (2011:76) menyebutkan: 1) Musyarakah/mudharabah merupakan model bank syari'ah yang memiliki korelasi positif dengan pertumbuhan sektor riil; 2) Hambatan yang dihadapi dalam pembiayaan musyarakah/mudharabah yaitu resiko kerugian dalam usaha/bisnis, dan bank syariah belum menjadikan skema ini sebagai produk utama. Hambatan ini dapat direduksi dengan cara inovasi; 3) Keuntungan yang akan didapat melalui mekanisme musyarakah/mudharabah: investasi akan meningkat, pembukaan lapangan kerja baru, tingkat pengangguran dapat dikurangi dan pendapatan masyarakat akan bertambah. Keuntungan lain, secara profit depositor/investor akan menanamkan uangnya di bank syariah jika ternyata rate of return bank syari'ah lebih besar dibandingkan interest rate di bank 
konvensional.

Yuli Anisah dalam penelitiannya yang berjudul Pengaruh Sistem Profit Sharing Terhadap Keinginan Nasabah Untuk Berinvestasi Pada Baitul Maal Wa Tamwil (BMT) Di Kota Banda Aceh, menyimpulkan Profit Sharing membuat keinginan berinvestasi menunjukkan sebesar 0,452 pada taraf signifikansi 1 persen. pengujian hipotesis diperoleh bahwa Ha diterima yang berarti bahwa antara $\mathrm{x}$ dengan y terdapat pengaruh yang signifikan. Sistem bagi hasil di lembaga keuangan syari'ah memberi mempengaruhi minat para nasabah untuk menanamkan menabung dilembaga keuangan syariah BMT.Dari tahun ketahun, dengan penambahan jumlah nasabah yang terus menerus (Anisah, 2016:6).

Nik Amah dalam tulisannya memberikan kesimpulan bahwa dengan prinsip syariah Islam perbankan Syariah berperan penting dalam menggerakkan roda perekonomian Indonesia melalui pengembangan dan pemberdayaan UMKM. Baik secara langsung maupun tidak langsung, perbankan syariah juga menyokong peran penting UMKM dalam pertumbuhan ekonomi, menjaga kestabilan perekonomian, penyerapan tenaga kerja, mendistribusikan hasil-hasil pembangunan, mengembangkan dunia usaha, serta penambahan APBN dan APBD melalui perpajakan. Perbankan syariah juga turut andil dalam menarik investor luar negeri ke Indonesia dengan adanya berbagai peluang investasi syariah di Indonesia.

Dini Arwati dalam tulisannya menyebutkan bahwa Perbankan Syariah lebih tepat memilih mitra kerjanya kepada UMKM yang jumlahnya banyak, sesungguhnya pemahaman mengenai ekonomi syariah, penerapan akuntansi syariah, penyaluran pembiayaan syariah, dan penghimpunan dana syariah lebih cepat dan sesuai sasaran. Untuk menetapkan besarnya bagi hasil dalam pembiayaan syariah ini tentunya diperlukan perangkat yang standar. Informasi ini biasanya disebut dengan Laporan Keuangan. Dalam hubungan perbankan syariah maupun non syariah dengan UKM, maka dari pihak UKM harus bisa menyediakan laporan keuangan yang dapat diandalkan.

Landasan teori dalam penelitian ini yang pertama akad pembiayaan mudharabah di bank syariah. Mudharabah berasal dari kata adhdharbu fil ardhi, yaitu berpergian untuk urusan dagang. Firman Allah dalam surat 73 ayat 20 . "Mereka bepergian di muka bumi mencari karunia Allah. 'Disebut juga qiradh yang berasal dari kata al-qardhu yang berarti al-qath'u (potongan), karena pemilik memotong sebagian hartanya untuk diperdagangkan dan memperoleh sebagian keuntungan (Sudarsono, 2005:67).

Secara teknis mudharabah adalah akad kerjasama usaha antara dua pihak dimana pihak pertama (shahibul maal) menyediakan seluruh modal, sedangkan pihak lainnya menjadi pengelola. Keuntungan usaha secara mudharabah dibagi menurut kesepakatan yang dituangkan dalam kontrak, sedangkan apabila rugi ditanggung oleh pemilik modal selama kerugian itu bukan akibat kelalaian si pengelola.Seandainya kerugian itu diakibatkan karena kecurangan atau kelalaian si pengelola, si pengelola harus bertanggungjawab atas kerugian tersebut.

Landasan Hukum Mudharabah dalam Al-Qur'an yaitu :

"Dan jika dari orang-orang yang berjalan di muka bumi mencari sebagian karunia Allah SWT."(QS. Al-Muzzamil :20)

"Apabila telah ditunaikan shalat maka bertebarlah kamu di muka bumi dan carilah karunia Allah SWT".(QS. Al-Jumuah : 10)

Sedangkan dalam Al-Hadist 
"Diriwayatkan dari Abbas bahwa Abbas Bin Abdul Muthalib jika memberikan dana kemitra usahanya secara mudharabah ia mensyaratkan agar dananya tidak dibawa mengarungi lautan, menuruni lembah yang berbahaya, atau membeli ternak. Jika menyalahi peraturan tersebut, yang bersangkutan bertanggungjawab atas dana tersebut. Disampaikanlah syarat-syarat tersebut kepada Rasulullah SAW dan Rasulullah pun membolehkannya"(HR.Thabrani)

Dari Shalih bin Suaib bahwa Rasulullah SAW bersabda, "Tiga hal yang didalamnya terdapat keberkatan: jual-beli secara tangguh, muqharadhah (mudharabah), dan mencampuradukkan dengan tepung untuk keperluan rumah bukan untuk di jual"(HR. Ibnu Majah).

Adapun rukun mudharabah yaitu: ada pemilik dana, ada usaha yang akan dibagi-hasilkan, ada nisbah, ada ijab qabul.

Fuqaha sepakat diperbolehkannya syirkah mudharabah. Kebolehan ini juga berdasarkan ijma' yang disandarkan kepada ayat-ayat al-qur'an dan hadisthadist Nabi saw. Disamping itu, umat manusia sangat membutuhkannya karena tidak semua orang yang mempunyai harta memiliki keahlian dalam mendayagunakan dan mengembangkan hartanya. Begitu pula sebaliknya, tidak semua orang yang mampu mengembangkan harta dan melakukan pekerjaan mempunyai modal. Dengan demikian, eksistensi syirkah mudharabah dapat merealisasikan kemaslahatan kedua belah pihak (Ath-Thayyar, 2009:287).

Secara spesifik terdapat bentuk musyarakah yang popular dalam produk perbankan syari'ah yaitu mudharabah. Mudharabah adalah bentuk kerjasama antara dua atau lebih pihak dimana pemilik modal (shahibul maal) mempercayakan sejumlah modal kepada pengelola (mudharib) dengan suatu perjanjian pembagian keuntungan. Bentuk ini menegaskan kerjasama dengan kontribusi $100 \%$ modal dari shahibul maal dan keahlian dari mudharib.Transaksi jenis ini tidak mensyaratkan adanya wakil shahibul maal dalam manajemen proyek. Sebagai orang kepercayaan, mudharib harus bertindak hati-hati dan bertanggung jawab untuk setiap kerugian yang terjadi akibat kelalaian. Sedangkan sebagai wakil shahibul maal dia diharapkan untuk mengelola modal dengan cara tertentu untuk menciptakan laba optimal.

Pembiayaan mudharabah yang ada pada perbankan syari'ah merupakan produk unggulan yang seharusnya dikembangkan oleh bank-bank syari'ah yang ada sekarang ini.Pembiayaan mudharabah sangat relevan dalam upaya untuk meningkatkan produktifitas sektor rill dengan memberikan pembiayaan mudharabah yang dapat meningkatkan potensi dunia usaha terutama UKM dalam meningkatkan jumlah dan kualitas produksinya.Namun pada kenyatannya pembiayaan mudharabah seakan produk yang sangat ditakuti oleh bank-bank syari'ah yang membuat mereka lebih memilih murabahan sebagai produk yang paling banyak menghasilkan bagi bank syari'ah.Ini tidak terlepas dari besarnya risiko pada pembiayaan mudharabah, sementera murabahah cenderung memiliki risiko yang jauh lebih kecil daripada pembiayaan mudharabah.

Keadaan dunia usaha yang tidak menentu dan susah diprediksi dan belum lagi kurangnya sumber daya manusia yang berkompeten dalam menjalankan sebuah usaha membuat risiko pemberian kredit modal kerja menjadi sangat besar. Tapi dengan keadaan seperti itu pihak bank syari'ah seakan menerimanya apa adanya tanpa melakukan terobosan yang berarti untuk meningkatkan kinerjanya dalam meningkatkan pembiayaan mudharabah(www.porakranjau.wordpress.com).

Perbedaan yang esensial dari musyarakah dan mudharabah terletak 
pada besarnya kontribusi atas manajemen dan keuangan atau salah satu diantara itu. Dalam mudharabah modal hanya berasal dari satu pihak, sedangkan dalam musyarakah modal berasal dari dua pihak atau lebih. musyarakah dan mudharabah dalam literatur fiqih berbentuk perjanjian kepercayaan (uqud al amanah) yang menuntut tingkat kejujuran yang tinggi dan menjunjung keadilan. Karenanya masing-masing pihak harus menjaga kejujuran untuk kepentingan bersama dan setiap usaha dari masing-masing pihak untuk melakukan kecurangan dan ketidakadilan pembagian pendapatan betul-betul akan merusak ajaran Islam.

Secara singkat mudharabah atau penanaman modal adalah penyerahan modal uang kepada orang yang berniaga sehingga ia mendapatkan persentase keuntungan. Sebagai suatu bentuk kontrak, mudharabah merupakan akad bagi hasil ketika pemilik dana/ modal (pemodal), biasa disebut shahibul maal, menyediakan modal $100 \%$ kepada pihak yang mampu mengelolah biasa disebut mudharib, untuk melakukan aktivitas produktif dengan syarat bahwa keuntungan yang dihasilkan akan dibagi diantara mereka menurut kesepakatan yang ditentukan sebelumnya dalam akad (yang besarnya juga dipengaruhi oleh kekuatan pasar).

Secara spesifik terdapat bentuk musyarakah yang popular dalam produk perbankan syariah yaitu mudharabah. Mudharabah adalah bentuk kerjasama antara dua atau lebih pihak dimana pemilik modal (shahibul maal) mempercayakan sejumlah modal kepada pengelola (mudharib) dengan suatu perjanjian pembagian keuntungan. Bentuk ini menegaskan kerjasama dengan kontribusi $100 \%$ modal dari shahibul maal dan keahlian dari mudharib.Transaksi jenis ini tidak mensyaratkan adanya wakil shahibul maal dalam manajemen proyek. Sebagai orang kepercayaan, mudharib harus bertindak hati-hati dan bertanggung jawab untuk setiap kerugian yang terjadi akibat kelalaian. Sedangkan sebagai wakil shahibul maal dia diharapkan untuk mengelola modal dengan cara tertentu untuk menciptakan laba optimal.

Pembiayaan mudharabah yang ada pada perbankan syari'ah merupakan produk unggulan yang seharusnya dikembangkan oleh bank-bank syari'ah yang ada sekarang ini. Pembiayaan mudharabah sangat relevan dalam upaya untuk meningkatkan produktifitas sektor rill dengan memberikan pembiayaan mudharabah yang dapat meningkatkan potensi dunia usaha terutama UKM dalam meningkatkan jumlah dan kualitas produksinya. Namun pada kenyatannya pembiayaan mudharabah seakan produk yang sangat ditakuti oleh bank-bank syari'ah yang membuat mereka lebih memilih murabahan sebagai produk yang paling banyak menghasilkan bagi bank syari'ah. Ini tidak terlepas dari besarnya risiko pada pembiayaan mudharabah, sementera murabahah cenderung memiliki risiko yang jauh lebih kecil daripada pembiayaan mudharabah.

Keadaan dunia usaha yang tidak menentu dan susah diprediksi dan belum lagi kurangnya sumber daya manusia yang berkompeten dalam menjalankan sebuah usaha membuat risiko pemberian kredit modal kerja menjadi sangat besar. Tapi dengan keadaan seperti itu pihak bank syari'ah seakan menerimanya apa adanya tanpa melakukan terobosan yang berarti untuk meningkatkan kinerjanya dalam meningkatkan pembiayaan mudharabah(www.porakranjau.wordpress.com).

Perbedaan yang esensial dari musyarakah dan mudharabah terletak pada besarnya kontribusi atas manajemen dan keuangan atau salah satu diantara itu. Dalam mudharabah modal hanya berasal dari satu pihak, sedangkan 
dalam musyarakah modal berasal dari dua pihak atau lebih. musyarakah dan mudharabah dalam literatur fiqih berbentuk perjanjian kepercayaan (uqud al amanah) yang menuntut tingkat kejujuran yang tinggi dan menjunjung keadilan. Karenanya masing-masing pihak harus menjaga kejujuran untuk kepentingan bersama dan setiap usaha dari masing-masing pihak untuk melakukan kecurangan dan ketidakadilan pembagian pendapatan betul-betul akan merusak ajaran Islam.

Ketentuan umum pembiayaan mudharabah sebagai berikut: Yang pertama jumlah modal yang diserahkan kepada nasabah selaku pengelola modal; harusdiserahkan tunai, dapat berupa uang atau barang yang dinyatakan nilainya dalam satuan uang. Apabila modal diserahkan secara bertahap, harus jelas tahapannya dan disepakati bersama. Kedua, hasil dan pengelolaan modal pembiayaan mudharabah dapat diperhitungkan dengan dua cara yaitu Perhitungan dari pendapatan proyek (revenue sharing) dan Perhitungan dari keuntungan proyek (profit sharing). Ketiga, Hasil usaha dibagi sesuai dengan persetujuan dalam akad, pada setiap bulan atau waktu yang disepakati. Bank selaku pemilik modal menanggung seluruh kerugian kecuali akibat kelalaian dan penyimpangan pihak nasabah, seperti penyeleweng-an, kecurangan dan penyalahgunaan dana. Keempat, Bank berhak melakukan pengawasan terhadap pekerjaan namun tidak berhak mencampuri urusan pekerjaan/usaha nasabah. Jika nasabah cidera janji dengan sengaja misalnya tidak mau membayar kewajiban atau menunda pembayaran kewajiban, dapat dikenakan sanksi administrasi.

Terkait dengan produk pembiayaan Mudharabah di bank syari'ah telah diatur dalam Fatwa Dewan Syari'ah Nasional NO: 08/DSN-MUI/IV/2000 Tentang Pembiayaan Mudharabah (QIRADH)'. berikut :

Fitur dan Mekanisme Pembiayaan Akad Mudharabah adalah sebagai

1. Bank bertindak sebagai pemilik dana (shahibul maal) yang menyediakan dana dengan fungsi sebagai modal kerja, dan nasabah bertindak sebagai pengelola dana (mudharib) dalam kegiatan usahanya.

2. Bank memiliki hak dalam pengawasan dan pembinaan usaha nasabah walaupun tidak ikut serta dalam pengelolaan usaha nasabah, antara lain Bank dapat melakukan review dan meminta bukti-bukti dari laporan hasil usaha nasabah berdasarkan bukti pendukung yang dapat dipertanggungjawabkan.

3. Pembagian hasil usaha dari pengelolaan dana dinyatakan dalam nisbah yang disepakati.

4. Nisbah bagi hasil yang disepakati tidak dapat diubah sepanjang jangka waktu investasi, kecuali atas dasar kesepakatan para pihak.

5. Jangka waktu Pembiayaan atas dasar Akad Mudharabah, pengembalian dana, dan pembagian hasil usaha ditentukan berdasarkan kesepakatan Bank dan nasabah.

6. Pembiayaan atas dasar Akad Mudharabah diberikan dalam bentuk uang dan/atau barang, serta bukan dalam bentuk piutang atau tagihan.

7. Dalam hal Pembiayaan atas dasar Akad Mudharabah diberikan dalam bentuk uang harus dinyatakan secara jelas jumlahnya.

8. Dalam hal Pembiayaan atas dasar Akad Mudharabah diberikan dalam bentuk barang, maka barang tersebut harus dinilai atas dasar harga pasar (net realizable value) dan dinyatakan secara jelas jumlahnya. 
9. Pengembalian Pembiayaan atas dasar Mudharabah dilakukan dalam dua cara, yaitu secara angsuran ataupun sekaligus pada akhir periode Akad, sesuai dengan jangka waktu Pembiayaan atas dasar Akad Mudharabah.

10. Pembagian hasil usaha dilakukan atas dasar laporan hasil usaha pengelola dana (mudharib) dengan disertai bukti pendukung yang dapat dipertanggungjawabkan.

11. Kerugian usaha nasabah pengelola dana (mudharib) yang dapat ditanggung oleh Bank selaku pemilik dana (shahibul maal) adalah maksimal sebesar jumlah pembiayaan yang diberikan (ra'sul maal).

Landasan teori yang kedua yaitu mengenai sektor riil UMKM. Usaha mikro merupakan usaha yang dikelola oleh individu atau keluarga atau beberapa orang yang belum memiliki izin usaha secara lengkap (Alim, 2009:14). Dalam UU No. 20 tahun 2008 tentang UMKM bahwa unit usaha mikro adalah usaha produktif yang dimiliki orang per orang dan/atau badan usaha perorangan yang memenuhi kriteria usaha mikro sebagaimana yang diatur dalam udang-undang (UU No. 20 tahun 2008) tentang usaha mikro, kecil, dan menengah.Sedangkan menurut Musa Hubeis, usaha kecil yang benar-benar kecil dan mikro dapat dikelompokkan atas pengertian: 1) Usaha kecil mandiri, yaitu tanpa menggunakan tenaga kerja lain; 2) Usaha kecil yang menggunakan tenaga kerja anggota keluarga sendiri; dan 3) Usaha kecil yang memiliki tenaga kerja upahan yang tetap. Usaha kecil dengan kategori yang dimaksud adalah yang sering dipandang sebagai usaha yang banyak menghadapi kesulitan, terutama yang terkait dengan lemahnya kemampuan manejerial, teknologi, dan permodalan yang terbatas, SDM, pemasaran, dan mutu produk. Faktor eksternal dalam usaha kecil merupakan hambatan yang sulit diatasi, yaitu struktur pasar yang kurang sehat dan berkembangnya perusahaan-perusahaan asing yang menghasilkan produk sejenis untuk segmen pasar yang sama (Hubeis, 2009:18).

Pengertian lain dikemukakan Sumitro (2004:168), usaha mikro kecil dan menengah adalah usaha yang dilakukan oleh suatu perusahaan dengan tenaga kerja yang digunakan tidak melebihi dari 50 orang. Adapun menurut Prawirokusumo (2000:48), karakteristik usaha kecil : 1)Biasanya usaha kecil dikelola oleh pemiliknya sehingga disebut owner-manager yang biasanya bertindak sebagai pimpinan yang memberikan arahan kepada beberapa staf yang tidak terlalu banyak dan tidak berspesialisasi untuk menjalankan usaha. Mereka disebut managemen team yang biasanya berasal dari anggota famili, sanak saudara, atau teman dekat; 2)Usaha kecil biasanya hanya mempunyai singel product line tidak diversifikasi usaha, volume usaha relatif kecil; 3)Penanggung jawab pengambilan keputusan biasanya dipegang oleh satu orang dan kurang memberikan wewenang kepada orang lain (very little or no delegation of authority); 4)Hubungan antara managemen dengan pekerjanya bersifat sangat dekat (close management-employee relationship); 5)Biasanya organisasi usaha tanpa adanya spesialisasi fungsional (has few or sometimes no functional specialist, such as a full time accountant or a personal manager); 6)Dalam sistem pelaporan juga tidak bertingkat (has no more than two tiers of managemen reporting); 7)Kurang mempunyai long term planning; 8)Biasanya tidak go public; 9)Lebih berorientasi kepada survival untuk menjaga ownwer's equity dari pada provit maximusasi; 10)Tidak dominan dalam pasar.

Penerapan ekonomi islam sebagai ekonomi yang berkeadilan dan bebas riba, dan selalu mengedepankan kepantingan bersama. Suatu perekonomian akan dilihat lebih baik jika seluruh masyarakatnya terlibat dalam pembangunan 
dan kesejahteraan yang diperoleh dapat merata, tidak pihak yang dirugikan. Sangat relevan dan menjadi solusi dari permasalahan ekonomi yang ada saat ini, terjadinya ketidak seimbangan antara masyarakat. Semuanya akan membangkitkan semangat manusia terus giat bekerja. Dihapuskannya riba dalam perekonomian, maka tidak akan ada sekat, semuanya sama dapat bekerja dengan baik sesuai yang diharapkan dengan bekerja giat. Bekerja sangat diharapkan dalam islam untuk memakmurkan bumi yang menjadi tujuan maqasidus syariah (Yusuf, 1997:111). Peningkatan sektor riil harus diutamakan perannya, baik dalam tataran internasioanal maupun dalam tataran domestik, yang menumbuhkembangkan dukungan nyata terhadap Usaha Mikro, Kecil, dan Menengah (UMKM).

Semua orang diperlakukan sama dalam memperoleh kesempatan, tidak ada perbedaan antarindividu atau kelompok atau kelas dalam masyarakat. Setiap individu harus mendapatkan kesempatan yang sama untuk hidup secara layak, belajar, bekerja, bekerja, jaminan keamanan, jaminan kesehatan, dan kesempatan pemenuhan hak-hak kemanusiaan lainnya. Kesejahteraan dan hasil pembangunan didistribusikan harus kepada setiap orang dan tidak mengumpul pada kelompok tertentu (Munrokim, 2008:67-68).

Ekonomi domestik adalah ekonomi kita yang sebenarnya, tidak akan ada campur tangan dari Negara lain sehingga jika terjadi masalah ekonomi dengan Negara lain maka tidak memberikan dampak apapun bagi Negara ini. Terbukti jika terjadi krisis ekonomi dunia maka perekonomian domestik menjadi perhatian dan solusi mengatasinya, sebab tidak terkena dampaknya. Jadi sebaiknya ekonomi di sektor rill khususnya tataran domestik harus menjadi perhatian bersama terutama bagi pemerintah. Peluang tetap terbuka dari sejumlah keunggulan yang kini ada dalam perekonomian Indonesia, seperti pasar dalam negeri yang besar, peluang investasi yang masih terbuka luas, dan sejumlah produk unggulan di pasar ekspor. Adanya intervensi pemerintah dalam ekonomi islam terhadap perekonomian sangat dibutuhkan, sebab Negara menjadi wadah terciptanya kesejahteraan ummat manusia. Dalam kepemilikan individu tidaklah bersifat mutlak, namun kepemilikan itu dibatasi oleh beberapa hal. Dalam beberapa kondisi, negara mempunyai hak intervensi terhadap kepemilikan, hak untuk membatasi atau mengatur kepemilikan itu dalam kehidupan masyarakat.

\section{METODE PENELITIAN \\ Jenis Penelitian}

Jenis penelitian yang digunakan dalam tulisan ini adalah dengan menggunakan studi pustaka yang diperoleh dari beberapa sumber.

\section{Sifat Penelitian}

Penelitian ini bersifat deskriptif kualitatif yang artinya menggambarkan suatu subyek penelitian. Dalam hal ini adalah bentuk produk pembiayaan dana bagi pihak ketiga yang menggunakan akad mudharabah di bank syari'ah. Kemudian tentang potensi pengembangan produk pembiayaan mudharabah bagi hasil pasti di bank syari'ah bagi sektor riil khususnya bagi UMKM.

\section{Jenis Data}

Jenis data yang digunakan dalam tulisan ini adalah data kualitatif yang bersumber dari data primer dan data sekunder. Data primer berupa sumber data yang langsung memberikan data kepada peneliti atau data yang diperoleh 
langsung dari lapangan (objek penelitian), sedangkan data sekunder adalah sumber data yang tidak langsung memberikan data kepada pengumpul data (peneliti) atau data yang diambil peneliti sebagai pendukung atas penelitian secara ilmiah yaitu dengan melakukan studi pustaka (penelusuran melalui buku, artikel, jurnal, majalah, internet dan sumber lainnya) (Farizal, 2010:66).Data-data yang digunakan penulis antara lain:1)Teori-teori yang peneliti ambil dari berbagai literature, 2) Pengambilan data-data dari hasil yang telah tersaji dari suatu lembaga.

\section{Batasan Penelitian}

Batasan dalam tulisan ini difokuskan pada produk penyaluran dana yang menggunakan akad mudharabah yang ada di bank syari'ah. Potensi pengembangan produk pembiayaan mudharabah di Bank Syariah bagi sektor riil khususnya UMKM..Batasan dalam tulisan ini juga pada kondisi faktual dari produk mudharabah di bank syari'ah, yang terjadi pada bank syari'ah saat ini yang market sharenya masih dibawah $5 \%$ apabila dibandingkan perbankan secara nasional.

\section{Teknik Pengumpulan Data}

Teknik pengumpulan data yang diperlukan dalam tulisan ini adalah dengan menggunakan beberapa metode yaitu:1)Studi Kepustakaan, Metode ini digunakan untuk menggali dasar-dasar teori yang terkait produk pembiayaan dana dengan akad mudharabah dan terkait dengan Usaha Kecil dan Menengah (UMKM), 2) Pengamatan, Setiap data yang didapatkan dari berbagai sumber diamati dan dianalisa terkait dengan kondisi produk mudharabah di bank syariah.

\section{Analisis data}

Metode analisis data yang digunakan adalah dengan menggunakan pendekatan kualitatif deskriptif yaitu dengan cara memaparkan metode teori produk pembiayaan mudharabah dana di bank syari'ah, melalui potensi pengemembangan akad mudharabah dalam memberikan pembiayaan bagi sektor riil khususnya UMKM. Kemudian bagaimana penerapannya di bank syari'ah sebagi produk yang bisa disalurkan bagi usaha masyarakat.

Penelitian kualitatif adalah prosedur penelitian yang menghasilkan data deskriptif berupa kata-kata tertulis atau lisan dari orang-orang dan keadaan yang diamati. Penelitian kualitatif adalah metode penelitian yang digunakan untuk meneliti pada kondisi objek yang alamiah, (sebagai lawannya adalah eksprimen) dimana peneliti adalah sebagai instrument kunci, teknik pengumpulan data dilakukan secara trianggulasi (gabungan), analisa data bersifat induktif dan hasil dari penelitian kualitatif lebih bersifat makna daripada generalisasi. 


\section{HASIL DAN PEMBAHASAN}

Pembiayaan Mudharabah di Bank Syariah

Tabel 2

Pembiayaan Mudharabah di Bank Syariah (Dalam Milyar Rupiah)

\begin{tabular}{ccccc}
\hline \multirow{2}{*}{ NO } & JENIS & DESEMBER & DESEMBER & PERTUMBUHAN \\
& PEMBIAYAAN & 2014 & 2015 & $\%$ \\
\hline 1 & MURABAHAH & 117.371 & 122.111 & $4,038 \%$ \\
2 & MUDHARABAH & 14.354 & 14.802 & $3,142 \%$ \\
3 & MUSYARAKAH & 49.336 & 60.713 & $23,060 \%$ \\
\hline
\end{tabular}

Sumber : Ototitas Jasa Keuangan Diolah, 2015

Dari data diatas menunjukkan bahwa pertumbuhan produk pembiayaan dengan akad mudharabah lebih kecil jika dibandingkan dengan pertumbuhan produk pembiayaan murabahah dan musyarakah. Hal ini menunjukkan bahwa bank syariah yang dikenal dengan konsep bagi hasil perlu didorong agar lebih mengedepankan pembiayaan mudharabah dengan prinsip bagi hasil. Bank syariah bagian dari ekonomi islam, yang seharusnya kehadirannya bisa menopang perkembangan sektor riil khususnya usaha UMKM. Dalam ekonomi islam harta harus beredar tidak menumpuk pada individu atau kelompok tertentu. Maka mekanisme pembiayaan mudharabah di bank syariah menjadi jalan mengedarkan harta dari pihak yang kelebihan dana kepada pihak yang membutuhkan dana. UMKM perlu dibantu dalam hal permodalan, tetapi tdak memberatkan para pelaku usaha, mudharabah menjadi yang tepat bagi pembiayaan UMKM karena tidak ada kewajiban pengembalian dari usaha. Jika usaha tersebut akan dibagi sesuai kesepakatan, dan jika terjadi kerugian diluar kesengajaan pelaku UMKM maka kerugian akan ditanggung bersama.

\section{Perkembangan UMKM}

Data Kemenkop UKM pada tahun 2011 jumlah UMKM meningkat menjadi 55,2 juta. $7,39 \%$ lebih tinggi dari usaha besar yang hanya 6,49\%.Sedangkan jumlah tenaga kerja UMKM 101,7 juta orang berbeda jauh dari usaha besar yang hanya 2,89 juta orang(www.seputarukm.com).

UKM dalam memiliki peranan besar dalam meningkatkan pertumbuhan perekonomian Indonesia karena dengan banyaknya jumlah penduduk Indonesia, UKM berperan untuk menambah lapangan pekerjaan. UKM dapat menyerap sebesar $97 \%$ tenaga kerja Indonesia, terutama dalam mikro ekonomi yang mencapai hampir 95\% tenaga kerja. Dari pemaparan di atas mengenai pertumbuhan perekonomian Indonesia tidak disebutkan bahwa UKM memiliki kontribusi dalam PDB yang mencapai 4.303 triliun/tahun. Selain itu, untuk membangun perekonomian suatu negara, dibutuhkan SDM yang memiliki jiwajiwa entrepreneur untuk mengembangkan kewirausahaan suatu negara. Hal tersebut dilakukan karena menurut Joseph A. Schumpeter, perekonomian suatu negara dapat berkembang dengan adanya suatu produk inovasi yang dapat dihasilkan melalui kewirausahaan. Di Indonesia sendiri usaha mikro jumlahnya mencapai $98,82 \%$ dan usaha kecil jumlahnya hanya 1,09\%. Hal tersebut menandakan masih banyaknya usaha-usaha yang tergolong mikro dan tidak mengalami perkembangan berarti karena tidak adanya kenaikan level dari mikro ke kecil, kecil ke menengah, dan seterusnya (www.kompasiana.com). 
Tabel 3

Perkembangan UMKM pada Periode 2010 - 2012

\begin{tabular}{|c|c|c|c|c|c|}
\hline No & Indikator & Satuan & 2010 & 2011 & 2012 \\
\hline 1 & Jumlah UMKM & Unit & 53823732 & 55206444 & 56534592 \\
\hline 2 & $\begin{array}{l}\text { Pertumbuhan } \\
\text { Jumlah UMKM }\end{array}$ & Persen & 2.01 & 2.57 & 2.41 \\
\hline 3 & $\begin{array}{l}\text { Jumlah Tenaga } \\
\text { Kerja UMKM }\end{array}$ & Orang & 99401775 & 101722458 & 107657509 \\
\hline 4 & $\begin{array}{l}\text { Pertumbuhan } \\
\text { Jumlah Tenaga } \\
\text { Kerja UMKM }\end{array}$ & Persen & 3.32 & 2.33 & 5.83 \\
\hline 5 & $\begin{array}{l}\text { Sumbangan } \\
\text { PDB UMKM } \\
\text { (harga } \\
\text { konstan) }\end{array}$ & Rp. Miliar & 1282571.80 & 1369326.00 & 1504928.20 \\
\hline 6 & $\begin{array}{l}\text { Pertumbuhan } \\
\text { sumbangan } \\
\text { PDB UMKM }\end{array}$ & Persen & 5.77 & 6.76 & 9.90 \\
\hline 7 & $\begin{array}{l}\text { Nilai Ekspor } \\
\text { UMKM }\end{array}$ & Rp. Miliar & 175894.89 & 187441.82 & 208067.00 \\
\hline 8 & $\begin{array}{l}\text { Pertumbuhan } \\
\text { Nilai Ekspor } \\
\text { UMKM }\end{array}$ & Persen & 8.41 & 6.56 & 11.00 \\
\hline
\end{tabular}

Sumber: Badan Pusat Statistik 2016, Diolah

\section{Potensi Perkembangan Produk Pembiayaan Mudharabah Di Bank Syariah Bagi Sektor Riil UMKM}

Melihat data perkembangan UMKM yang terus meningkat setiap waktu. UMKM lebih kokoh dalam memberi kontribusi dalam menggerakkan perekonomian suatu negara. Sehingga UMKM ini memerlukan dukungan dalam kegiatannya. Salah satu lembaga yang mampu menopang perkembangan UMKM adalah bank syariah. Bank Syariah memiliki produk pembiayaan dengan menggunakan akad mudharabah dengan sistem bagi hasil, dianggap sangat cocok dalam membantu umkm dalam hal permodalan. Akad pembiayaan mudharabah di bank syariah belum mendominasi dalam pembiayaan, sedangkan UMKM terus mengalami perkembangan sehingga membutuhkan produk yang tepat. Karakter pembiayaan mudharabah sangat tepat bagi UMKM yang terus berkembang. Sehingga potensi pengembangan produk pembiayaan mudharabah pada UMKM masih sangat besar dan peluang masih terbuka luas.

\section{PENUTUP}

Produk pembiayaan mudharabah di bank syariah belum menjadi produk dominan dalam memberikan pembiayaan, padahal mudharabah menjadi cermin bagi bank syariah karena mudharabah menggunakan bagi hasil. Produk pembiayaan mudharabah terus berkembang walaupun perkembangannya lebih kecil jika dibanding dengan perkembangan produk jual beli murabahah.

Potensi pengembangan produk pembiayaan mudharabah di bank syariah masih sangat besar dan terus dapat ditingkatkan khususnya untuk pembiayaan sektor riil UMKM. Perkembangan UMKM terus meningkat sehingga dibutuhkan 
dorongan dalam hal permodalam. Produk pembiayaan mudharabah menjadi tepat dalam memberikan pembiayaan bagi UMKM, karena karakternya yang sangat relevan dengan kondisi dengan UMKM yang ada.

\section{DAFTAR PUSTAKA}

Ukm Dan Pertumbuhan Perekonomian Indonesia Sejalankah Dengan Persiapan Dalam Menghadapi Afta. http://www.kompasiana.com. Diakses tanggal 26 Pebruari 2016.

.Bank Syariah Lebih Melirik UMKM. http://www.bankmuamalat.co.id. Diakses tanggal 19 Pebruari 2016.

.BSM Patok Porsi Pembiayaan UMKM Jadi 75. http://www.syariahmandiri.co.id. Diaksestanggal 19 Pebruari 2016.

Peran Bank Syariah Dalam Mengembangan Usaha Kecil Menengah http://www.kompasiana.com. Diakses tanggal 19 Pebruari 2016.

.Perbankan Syariah. http://www.bi.go.id. Diakses tanggal 14 Juni 2012.

PotensiPembiayaanMudharabah.http://porakranjau.wordpress.com.

Diakses tanggal 9 April 2011.

.UMKM dan Masyarakat Ekonomi ASEAN 2015. http://www. seputarukm.com. Diakses tanggal 26 Pebruari 2016.

Abdul, Al-Mishri Sami'. 2006. Pilar-Pilar Ekonomi Islam. Yogyakarta:Pustaka Pelajar

Algaoud, Latifa Mdan Lewis, Mervyn K. 2001. Perbankan Syariah, Prinsip, Praktik, Prospek. Jakarta: PT. Serambi Ilmu Semesta.

Alim, Nizarul. 2009. Pembiayaan Syariah untuk Usaha Mikro dan Kecil: Studi Kasus Dan Solusi, Cetakan I. Surabaya: PT. Bina IImu.

Amah, Nik. Bank Syariah dan UMKM Dalam Menggerakkan Roda Perekonomian Indonesia: Suatu Kajian Literatur. Jurnal Assets: Jurnal Akuntansi dan PendidikanProgram Studi Pendidikan Akuntansi, FPIPSIKIP PGRI Madiun2(1).

Anisah, Yuli. 2012. Pengaruh Sistem Profit Sharing Terhadap Keinginan Nasabah Untuk Berinvestasi Pada Baitul Maal Wa Tamwil (BMT) Di Kota Banda Aceh.Jurnal Ekonomi Dan BisnisFEB Politeknik Negeri Louksumawe 12(1).

Antonio, Muhammad Syafii. 2000. Bank Islam: Teori dan Praktek. Jakarta: Gema Insani Press. 
Arwati, Dini. Peran Strategis Ekonomi Berbasis Syariah Dalam Pemberdayaan Ekonomi Sektor Usaha Mikro, Kecil, dan Menengah (UMKM), Ditinjau Dari Penerapan Akuntasi Syariah dan Akuntansi UMKM. Jurnal EkonoInsentif4(1).

Ath- Thayyar, Abdullah Muhammad Bin, dkk. 2009. Ensiklopedi Fiqih Muamalah Dalam Pandangan 4 Madzhab. Yogyakarta: Maktabah Al- Hanif.

Farizal. 2010. Pengembangan Kompetensi SDM Perbankan Syari'ah Melalui Corporate University. Forum Riset Perbankan Syariah IIYogyakarta. Universitas Muhammadiyah Yogyakarta.

Hakiem, Hilman dkk. 2011. Musyarakah, Mudharabah dan Pertumbuhan Sektor Riil.Jurnal Ekonomi Islam AL-InfaqProgram Studi Ekonomi Islam Fakultas IImu Agama Islam Universitas Ibnu Khaldun Bogor2(1).

Hubeis, Musa. 2009. Prospek Usaha Kecil Dalam Wadah Inkubator Bisnis, Cetakan I. Bogor: Galia Indonesia.

Kara, Muslimin. 2013. Kontribusi Pembiayaan Perbankan Syariah Terhadap Pengembangan Usaha Mikro, Kecil, dan Menengah. Jurnal Asy-Syir'ah Jurnal IImu Syariah dan Hukum Fakultas Syariah dan Hukum Universitas Islam Negeri Sunan Kalijaga Yogyakarta 47(1).

Munrokhim, Misanam,dkk. 2008. Ekonomi Islam. Jakarta: PT. Raja Grafindo Persada.

Otoritas Jasa Keuangan. 2014. Statistik Perbankan Syari'ah.

Prawirokusumo, Soeharto. 2000. Kewirausahaan Dan Manajemen Usaha Kecil. Yogyakarta: BPFE Yogyakarta.

Qardhawi, Yusuf. 1997. Norma dan Etika Ekonomi Islam. Yogyakarta: Penerbit Gema Insani Press.

Sudarsono, Heri.2005. Bank \& Lembaga Keuangan Syariah Deskripsi dan Ilustrasi, Edisi 3. Yogyakarta: EKONISIA.

Sumitro, Warkum.2004. Azas-azas Perbankan Islam dan Lembaga-lembaga Terkait. Jakarta: Raja Grafindo Persada.

Undang-undang No. 20 tahun 2008 tentang Usaha Mikro, Kecil, dan Menengah. 